\title{
Effect of various proteinase inhibitors on ovulation of explanted hamster ovaries
}

\author{
S. Ichikawa, H. Morioka, M. Ohta, K. Oda* and S. Murao* \\ Laboratory of Animal Reproduction and * Laboratory of Applied Microbiology, \\ College of Agriculture, University of Osaka Prefecture, Sakai City, Osaka 591, Japan
}

\begin{abstract}
Summary. Hamster ovaries explanted at $21: 00-24: 00 \mathrm{~h}$ on the day of pro-oestrus were incubated with microbial proteinase inhibitors until $10: 30 \mathrm{~h}$ on the next morning and the ovulatory blocking effect of these inhibitors was examined. Amongst 11 proteinase inhibitors examined, talopeptin, a specific inhibitor for metallo-proteinases, and $\alpha$ MAPI, a specific inhibitor for serine and thiol proteinases, were the strongest blockers. These 2 inhibitors exhibited a chronological discrepancy in their blocking effect on ovulation. S-SI, plasminostreptin, elastatinal, antipain and chymostatin, which are inhibitors for serine proteinases, partly but significantly inhibited ovulation. The results suggest that, in addition to a metallo-proteinase reported previously, a proteinase which is sensitive to $\alpha$-MAPI is essential for the ovulatory process, and that serine proteinase(s) also participate in ovulation of the hamster ovary.
\end{abstract}

\section{Introduction}

Since the initial report by Schochet in 1916, several studies have suggested that proteolytic enzymes are associated with the ovulatory process. The injection of proteolytic enzymes into the follicular antrum caused rupture of rabbit Graafian follicles (Espey \& Lipner, 1965). The follicle wall becomes flaccid and distensible in the final stages of the ovulatory process (Espey, 1967a, b; Rondell, 1970), and proteinases, such as collagenase, elastase, trypsin, $\alpha$-chymotrypsin and plasmin, weaken the tensile strength of the porcine follicle wall (Espey, 1970; Beers, 1975). Furthermore, several kinds of proteinases have been recognized in follicles (Espey, 1974; Fukumoto, Yajima, Okamura \& Midorikawa, 1981). A specific inhibitor of metallo-proteinase, talopeptin, completely blocked ovulation in the hamster ovary explanted at $21: 00$ and $22: 00 \mathrm{~h}$ on the day of pro-oestrus; the inhibition markedly decreased in ovaries excised at $23: 00 \mathrm{~h}$, whereas the integrity of the apex of the Graafian follicles of these ovaries was still maintained (Ichikawa, Ohta, Morioka \& Murao, 1983). These observations suggest that some proteinases other than collagenase may also be involved in the mammalian ovulatory process before and after collagenolysis.

The present study was designed to confirm the participation of proteolytic enzymes other than metallo-proteinases in the ovulatory process by utilizing a series of microbial proteinase inhibitors which cover all proteinase groups, i.e. carboxyl-, metallo-, thiol- and serine proteinases. The temporal relationship between treatment and inhibition by the collagenase and other proteinase inhibitors was also studied. 


\section{Materials and Methods}

The methods of animal handling and ovarian incubation have been described previously (Ichikawa et al., 1983). Female hamsters were housed at $24 \pm 2^{\circ} \mathrm{C}$ under a light schedule of $14 \mathrm{~h}$ light (05:00$19: 00 \mathrm{~h}$ ). Animals showing 4-day cycles and weighing 80-150 g were used. Ovaries were excised on the day of pro-oestrus at specified times $\pm 15 \mathrm{~min}$ and incubated in the medium until 10:30 hon the following day. The ovaries from each hamster were treated differently, so that ovaries in each treatment were taken from different animals. Ova in the oviducts and in the culture medium were counted under a dissecting microscope at the time of autopsy and at the end of incubation, respectively. Amongst the proteinase inhibitors used in this study, S-PI (Streptomyces pepsin inhibitor), talopeptin, thiolstatin, S-SI (Streptomyces subtilisin inhibitor) and $\alpha$-MAPI (microbial alkaline proteinase inhibitor) were prepared by S. Murao; elastatinal, leupeptin, antipain and chymostatin were purchased from the Peptide Institute, Inc., Osaka, Japan; E-64 was supplied by Dr S. Ohmura of Taisho Pharmaceutical Co., Tokyo and plasminostreptin by Dr A. Kakinuma of Takeda Pharmaceutical Co., Osaka, Japan. The inhibitory spectra of these proteinase inhibitors are shown in Table 1.

Table 1. Microbial proteinase inhibitors and their inhibitory spectra

\begin{tabular}{|c|c|c|}
\hline Proteinase inhibitor & Proteinase inhibited & Reference \\
\hline \multicolumn{3}{|l|}{ Carboxyl-proteinase inhibitor } \\
\hline S-PI (Ac-pepstatin) & $\begin{array}{l}\text { Pepsin, cathepsin } \mathbf{D}, \text { microbial acid } \\
\text { proteinase }\end{array}$ & $\begin{array}{l}\text { Murao \& Satoi (1971) } \\
\text { Satoi \& Murao (1973) }\end{array}$ \\
\hline \multicolumn{3}{|l|}{ Metallo-proteinase inhibitor } \\
\hline Talopeptin (MK-I) & $\begin{array}{l}\text { Thermolysin, collagenase, microbial } \\
\text { neutral proteinase }\end{array}$ & $\begin{array}{l}\text { Murao et al. (1980) } \\
\text { Fukuhara et al. (1982) }\end{array}$ \\
\hline \multicolumn{3}{|l|}{ Thiol proteinase inhibitor } \\
\hline E-64 & Papain, cathepsin B & Hanada et al. (1978) \\
\hline Thiolstatin & Papain, cathepsin $\mathbf{B}$ & S. Murao (unpublished data) \\
\hline \multicolumn{3}{|l|}{ Serine proteinase inhibitor } \\
\hline $\mathrm{S}-\mathrm{SI}$ & Microbial alkaline proteinase & $\begin{array}{l}\text { Murao \& Sato (1972) } \\
\text { Sato \& Murao (1974) }\end{array}$ \\
\hline Plasminostreptin & $\begin{array}{l}\text { Plasmin, trypsin, microbial alkaline } \\
\text { proteinase }\end{array}$ & Kakinuma et al. (1978) \\
\hline Elastatinal & Elastase & Umezawa et al. (1973) \\
\hline \multicolumn{3}{|l|}{ Serine and thiol proteinase inhibitor } \\
\hline$\alpha$-MAPI & $\begin{array}{l}\alpha \text {-Chymotrypsin, papain, microbial } \\
\text { alkaline proteinase }\end{array}$ & $\begin{array}{l}\text { Murao \& Watanabe (1977) } \\
\text { Watanabe \& Murao (1979) }\end{array}$ \\
\hline Leupeptin & Trypsin, plasmin, papain & Aoyagi et al. (1969) \\
\hline Antipain & Trypsin, plasmin (weakly), papain & Suda et al. (1972) \\
\hline Chymostatin & Chymotrypsin, papain & Umezawa et al. (1970) \\
\hline
\end{tabular}

Antipain, chymostatin and $\alpha$-MAPI were dissolved in $50 \%$ methyl alcohol-saline $(9 \mathrm{~g} \mathrm{NaCl} / \mathrm{l})$ solution and the remaining inhibitors were dissolved in saline $(9 \mathrm{~g} \mathrm{NaCl} / 1)$, at a concentration of $0 \cdot 5,1.0,2 \cdot 0$ and 4.0 mM. The basic medium was Medium 199 (Nissui, Co., Tokyo) supplemented with $3.0 \mathrm{mg}$ glucose, $0.1 \mathrm{mg}$ L-glutamine, $0.05 \mathrm{mg}$ ascorbic acid, $0.035 \mathrm{mg}$ insulin, $1.9 \mathrm{mg}$ sodium bicarbonate, 100 units penicillin and $0.12 \mathrm{mg}$ streptomycin $/ \mathrm{ml}$. The inhibitor solution $(0.4 \mathrm{ml})$ was added to $10 \mathrm{ml}$ of the basic medium. Control ovaries were incubated in basic medium to which $0.4 \mathrm{ml}$ saline or $50 \%$ methyl alcohol-saline solution was added in place of the inhibitor solution. Since control values obtained in the two culture media were not statistically different, they were combined.

Differences in ovulation rate between inhibitor groups and non-inhibitor controls were assessed by Fisher's exact probability test and differences in mean number of ova by Student's $t$ test. 


\section{Results}

\section{Effects of various proteinase inhibitors on ovulation}

As shown in Table 2, the ovulatory inhibitory effects of talopeptin and $\alpha$-MAPI were the strongest amongst those of the 11 inhibitors examined. Talopeptin at a concentration of $0.16 \mathrm{~mm}$ completely blocked ovulation of all ovaries explanted at $21: 00 \mathrm{~h}$ on the day of pro-oestrus, and 17 ovaries treated with 0.08 and $0.16 \mathrm{mM}-\alpha$-MAPI ovulated only 5 ova in all. A dose of $0.02 \mathrm{~mm}-\alpha-$ MAPI effectively blocked ovulation. S-SI, plasminostreptin, antipain and chymostatin were less effective. The effect of antipain was not dose dependent. S-PI and elastatinal exhibited lesser but still significant effects.

Table 2. Effect of proteinase inhibitors on ovulation of hamster ovaries explanted at $21: 00 \mathrm{~h}$ on the day of pro-oestrus

\begin{tabular}{|c|c|c|c|c|}
\hline \multirow[b]{2}{*}{ Inhibitor } & \multirow{2}{*}{$\begin{array}{l}\text { Inhibitor } \\
\text { conc. } \\
\text { (mM) }\end{array}$} & \multicolumn{2}{|c|}{ No. of ovaries } & \multirow{2}{*}{$\begin{array}{l}\text { Mean } \pm \text { s.e.m. } \\
\text { no. of ova/ovary }\end{array}$} \\
\hline & & Examined & Ovulating & \\
\hline None (control) & - & 20 & 20 & $4 \cdot 3 \pm 0 \cdot 3$ \\
\hline \multirow[t]{2}{*}{ S-PI } & $0 \cdot 08$ & 8 & 7 & $3.0 \pm 0.6$ \\
\hline & $0 \cdot 16$ & 8 & 6 & $2 \cdot 0 \pm 0.7^{*}$ \\
\hline \multirow[t]{3}{*}{ Talopeptin } & 0.02 & 8 & 8 & $3 \cdot 1 \pm 0.4$ \\
\hline & 0.08 & 8 & $4 \dagger$ & $0.8 \pm 0.3^{*}$ \\
\hline & $0 \cdot 16$ & 8 & $0 \dagger$ & 0.0 \\
\hline E-64 & 0.08 & 4 & 4 & $4 \cdot 3 \pm 1 \cdot 3$ \\
\hline Thiolstatin & $0 \cdot 08$ & 8 & 8 & $3.5 \pm 0.6$ \\
\hline S-SI & 0.08 & 8 & 6 & $1.5 \pm 0.5^{*}$ \\
\hline \multirow[t]{2}{*}{ Plasminostreptin } & 0.04 & 4 & 4 & $3.0 \pm 0.4$ \\
\hline & 0.08 & 8 & 7 & $2 \cdot 1 \pm 0.6^{*}$ \\
\hline Elastatinal & 0.08 & 8 & 7 & $2.4 \pm 0.6^{*}$ \\
\hline \multirow[t]{3}{*}{$\alpha$-MAPI } & 0.02 & 6 & 5 & $1.2 \pm 0.4^{*}$ \\
\hline & 0.08 & 9 & $2 \dagger$ & $0.3 \pm 0.2^{*}$ \\
\hline & $0 \cdot 16$ & 8 & $2 \dagger$ & $0.3 \pm 0.2^{*}$ \\
\hline \multirow[t]{2}{*}{ Leupeptin } & 0.08 & 8 & 8 & $3.6 \pm 0.4$ \\
\hline & $0 \cdot 16$ & 8 & 7 & $4.0 \pm 0.7$ \\
\hline \multirow[t]{2}{*}{ Antipain } & 0.08 & 9 & $5 \dagger$ & $0.9 \pm 0.4^{*}$ \\
\hline & $0 \cdot 16$ & 8 & 7 & $1.9 \pm 0.4^{*}$ \\
\hline \multirow[t]{2}{*}{ Chymostatin } & 0.08 & 8 & 7 & $1.8 \pm 0.5^{*}$ \\
\hline & $0 \cdot 16$ & 8 & 7 & $1 \cdot 5 \pm 0.4^{*}$ \\
\hline
\end{tabular}
test.

$\dagger P<0.01$, compared to the control value by Fisher's exact probability

* $P<0.01$, compared to the control value by Student's $t$ test.

Table 3. Effect of $0 \cdot 16$ mM-talopeptin and $-\alpha$-MAPI on ovulation of hamster ovaries explanted at various times on the day of pro-oestrus

\begin{tabular}{|c|c|c|c|c|c|c|}
\hline \multirow{2}{*}{$\begin{array}{l}\text { Time of } \\
\text { explantation } \\
\text { (h) }\end{array}$} & \multicolumn{3}{|c|}{$\begin{array}{l}\text { No. of ovaries ovulating/ } \\
\text { no. of ovaries examined }\end{array}$} & \multicolumn{3}{|c|}{ Mean \pm s.e.m. no. of ova/ovary } \\
\hline & Control & Talopeptin & $\alpha$-MAPI & Control & Talopeptin & $\alpha$-MAPI \\
\hline $21: 00$ & $8 / 8$ & $0 / 8^{a * *}$ & $2 / 8^{\mathrm{ab} * *}$ & $4.4 \pm 0.4$ & $0.0 \pm 0.0$ & $0.3 \pm 0.2^{a * *}$ \\
\hline $22: 00$ & $8 / 8$ & $3 / 12^{\mathrm{a} * *}$ & $0 / 8^{a * *}$ & $4.6 \pm 0.5$ & $0.4 \pm 0.2^{\mathrm{a} * *}$ & $0.0 \pm 0.0$ \\
\hline $23: 00$ & $8 / 8$ & $12 / 12^{\mathrm{b}}$ & $5 / 10^{\mathrm{b} *}$ & $4.5 \pm 0.5$ & $2 \cdot 4 \pm 0.4^{b * *}$ & $0.7 \pm 0.3^{a * *}$ \\
\hline $24: 00$ & $8 / 8$ & $10 / 10^{b}$ & $7 / 10^{\mathrm{b}}$ & $4.8 \pm 0.6$ & $3 \cdot 1 \pm 0.5^{\mathrm{b} *}$ & $2.4 \pm 0.7^{\mathrm{b} *}$ \\
\hline
\end{tabular}

Within each column figures without a common alphabetical superscript differ significantly, $P<0.05$.

${ }^{*} P<0.05 ;{ }^{* *} P<0.01$ compared to the corresponding controls. 


\section{Temporal relationships of the blocking effects of proteinase inhibitors on ovulation}

Talopeptin and $\alpha$-MAPI strongly inhibited ovulation of ovaries explanted at $21: 00$ and $22: 00 \mathrm{~h}$ on the day of pro-oestrus (Table 3). The inhibitory effect of talopeptin decreased markedly in ovaries explanted at $23: 00 \mathrm{~h}$ or later, but strong inhibition by $\alpha$-MAPI was still observed in ovaries explanted at $23: 00 \mathrm{~h}$. Amongst the ovaries explanted at $24: 00 \mathrm{~h}, 2$ ovaries in the control group and 1 ovary in the talopeptin-treated group had already ovulated 1 or 2 ova when they were killed. These ova were excluded from the data.

The blocking effect of antipain, chymostatin and plasminostreptin on ovaries at 20:00 $\mathrm{h}$ was not different from the effect on ovaries at 21:00 h (Table 4).

Table 4. Effects of $0.08 \mathrm{~mm}$-antipain, -chymostatin and -plasminostreptin on ovulation of hamster ovaries explanted at $20: 00$ and $21: 00 \mathrm{~h}$ on the day

of pro-oestrus

\begin{tabular}{lccccc}
\hline & \multicolumn{2}{c}{$\begin{array}{c}\text { No. of ovaries ovulating/ } \\
\text { no. of ovaries examined }\end{array}$} & & Mean \pm s.e.m. no. of ova/ovary \\
\cline { 2 - 3 } \cline { 5 - 6 } \multicolumn{1}{c}{ Inhibitor } & $20: 00 \mathrm{~h}$ & $21: 00 \mathrm{~h}$ & $20: 00 \mathrm{~h}$ & $21: 00 \mathrm{~h}$ \\
\hline None & $14 / 16$ & $20 / 20$ & & $3 \cdot 6 \pm 0 \cdot 6$ & $4 \cdot 3 \pm 0 \cdot 3$ \\
Antipain & $7 / 8$ & $5 / 9^{* *}$ & $1 \cdot 5 \pm 0 \cdot 4^{*}$ & $0 \cdot 9 \pm 0 \cdot 4^{* *}$ \\
Chymostatin & $7 / 8$ & $7 / 8$ & & $1 \cdot 6 \pm 0 \cdot 5^{*}$ & $1 \cdot 8 \pm 0 \cdot 5^{* *}$ \\
Plasminostreptin & $6 / 8$ & $7 / 8$ & $1 \cdot 1 \pm 0 \cdot 3^{*}$ & $2 \cdot 1 \pm 0.6^{* *}$ \\
\hline
\end{tabular}

Values at $21: 00 \mathrm{~h}$ are cited from Table 2.

${ }^{*} P<0.05 ;{ }^{* *} P<0.01$ compared to the corresponding controls.

\section{Discussion}

We previously reported that a talopeptin-sensitive metallo-proteinase, probably collagenase, was indispensable for ovulation in the hamster ovary (Ichikawa et al., 1983). We now propose that another proteinase which is specifically inhibited by $\alpha$-MAPI is also indispensable for the ovulatory process. This is based on the following observations in the present study: (1) $\alpha$-MAPI, an inhibitor for serine- and thiol-proteinase, completely blocked ovulation of the explanted hamster ovary, as did talopeptin; (2) there was chronological discrepancy in the ovulatory blocking effect between talopeptin and $\alpha$-MAPI, i.e. $\alpha$-MAPI strongly inhibited ovulation of ovaries explanted at 23:00 h, whereas the inhibitory effect of talopeptin had decreased by this time. The proteolysis by the $\alpha$-MAPI-sensitive proteinase seems to proceed in succession, rather than in parallel, to the collagenolysis by metallo-proteinase. It is not known which protein is attacked by the $\alpha-\mathrm{MAPI}$ sensitive proteinase in the follicular wall, but the proteinase may degrade a protein involved in the junctional complex between cells or an adhesive protein, such as cell surface fibronectin which binds cells to other cells (Yamada \& Olden, 1978).

We have no data at present on the enzymic properties of the $\alpha$-MAPI-sensitive proteinase in the follicular wall, but it is unlikely that this enzyme is a chymotrypsin-like proteinase or thiolproteinase, both of which are specifically inhibited by $\alpha$-MAPI in vitro, because chymostatin, an inhibitor of chymotrypsin, was less effective than $\alpha$-MAPI in blocking ovulation, and E-64 and thiolstatin which are inhibitors of thiol proteinases were ineffective blockers (Table 5). Furthermore the $\alpha$-MAPI-sensitive proteinase is apparently different from serine proteinase, because serine proteinase inhibitors examined in this study were less effective than $\alpha$-MAPI or unable to block ovulation from ovaries explanted at $21: 00 \mathrm{~h}$ on the day of pro-oestrus (Table 5).

On the basis of various observations, Espey (1980) proposed that serine proteinases may participate in ovulation in mammals. In the present study S-SI, plasminostreptin, elastatinal, antipain and chymostatin, which are strong inhibitors against serine proteinases, significantly 
Table 5. Inhibition of proteinases and ovulation by proteinase inhibitors

\begin{tabular}{|c|c|c|c|c|c|c|c|}
\hline \multirow[b]{2}{*}{ Proteinase inhibitor } & \multicolumn{6}{|c|}{ Proteinase } & \multirow[b]{2}{*}{ 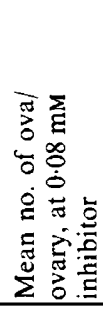 } \\
\hline & 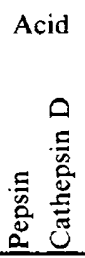 & 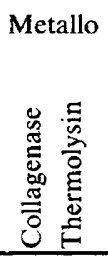 & 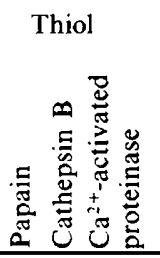 & $\frac{5}{2}$ & 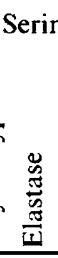 & 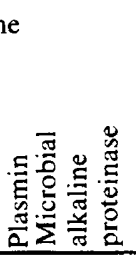 & \\
\hline $\begin{array}{l}\text { Acid } \\
\text { S-PI }\end{array}$ & ++ & -- & --- & -- & - & $-\quad-$ & $3 \cdot 0$ \\
\hline $\begin{array}{l}\text { Metallo } \\
\text { Talopeptin }\end{array}$ & -- & ++ & --- & -- & - & $-\quad-$ & $0.8^{*}$ \\
\hline $\begin{array}{l}\text { Thiol } \\
\text { E-64 } \\
\text { Thiolstatin }\end{array}$ & $\begin{array}{l}- \\
-\end{array}$ & $\begin{array}{l}- \\
-\end{array}$ & $\begin{array}{l}+++ \\
+++\end{array}$ & $\begin{array}{l}- \\
-\end{array}$ & - & $\begin{array}{ll}- & - \\
- & -\end{array}$ & $\begin{array}{l}4 \cdot 3 \\
3 \cdot 5\end{array}$ \\
\hline $\begin{array}{l}\text { Serine } \\
\text { S-SI } \\
\text { Plasminostreptin } \\
\text { Elastatinal }\end{array}$ & 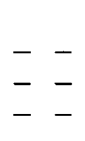 & $\begin{array}{ll}- & - \\
- & - \\
- & -\end{array}$ & $\begin{array}{l}-\quad-\quad- \\
-\quad-\quad- \\
-\quad-\quad-\end{array}$ & $\begin{array}{l}- \\
+ \\
-\end{array}$ & - & $\begin{array}{ll}- & + \\
+ & + \\
- & -\end{array}$ & $\begin{array}{l}1 \cdot 5^{*} \\
2 \cdot 1^{*} \\
2 \cdot 4^{*}\end{array}$ \\
\hline $\begin{array}{l}\text { Serine and thiol } \\
\alpha \text {-MAPI } \\
\text { Leupeptin } \\
\text { Antipain } \\
\text { Chymostatin }\end{array}$ & 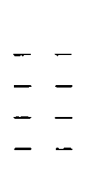 & $\begin{array}{ll}- & - \\
- & - \\
- & - \\
- & -\end{array}$ & $\begin{array}{l}+++ \\
+++ \\
+++ \\
+++\end{array}$ & $\begin{array}{l}- \\
+ \\
+ \\
+\end{array}$ & $\begin{array}{l}- \\
- \\
-\end{array}$ & $\begin{array}{ll}- & + \\
+ & + \\
\pm & \end{array}$ & $\begin{array}{l}0.3^{*} \\
3.6 \\
0.9^{*} \\
1.8^{*}\end{array}$ \\
\hline
\end{tabular}

The values in the last column are cited from Table 2 . The asterisk indicates significant difference $(P<0.01)$ when compared to the control value of 4.3 in Table 2.

inhibited ovulation of the hamster ovary (Table 5). These observations support Espey's (1980) hypothesis. However, the ovulatory blockage by these 5 inhibitors in the ovaries explanted at 20:00 and $21: 00 \mathrm{~h}$ was partial and not complete. Furthermore, leupeptin, a strong inhibitor of trypsin, was ineffective on ovaries explanted at $21: 00 \mathrm{~h}$. According to Werb \& Aggeler (1978), plasmin and other serine proteinases activate procollagenase to collagenase in inflamed tissues, and trypsin does so in the rat Graafian follicle (Morales, Woessner, Howell, Marsh \& LeMaire, 1978). It is therefore probable that the action of serine proteinase in the ovulatory process might have been essentially completed by the time of explantation of the ovaries at 20:00 h. If the inhibitors had been applied to ovaries explanted at 19:00 h or earlier they might have inhibited ovulation more strongly. However, when the hamster ovary was explanted at 19:00 h or earlier on the day of pro-oestrus and cultured by the method used in this study, the number of ova ovulated was too small to evaluate the ovulatory blocking effect of the inhibitor (Morioka \& Ichikawa, 1982).

In conclusion, the present results suggest that at least three kinds of proteinases, i.e. serine proteinase(s), metallo-proteinase and an $\alpha$-MAPI-sensitive proteinase, are involved in the ovulatory process of the hamster ovary, and that serine proteinases may act on the ovulatory process by $20: 00 \mathrm{~h}$ on the day of pro-oestrus, metallo-proteinase by $23: 00 \mathrm{~h}$ and the $\alpha$-MAPIsensitive proteinase by $24: 00 \mathrm{~h}$. While metallo-proteinase presumably degrades the collagen matrix in the follicular wall by $23: 00 \mathrm{~h}, \alpha$-MAPI-sensitive proteinase may act on other components of the follicular wall before rupture.

This work was supported in part by Scientific Research Grant No. 57560285 from the Japan Ministry of Education. 


\section{References}

Aoyagi, T., Takeuchi, T., Matsuzaki, A., Kawamura, K., Kondo, S., Hamada, M. \& Umezawa, H. (1969) Leupeptin, new protease inhibitors from Actinomycetes. J. Antibiot., Tokyo, Ser. A 22, 283-286.

Beers, W.H. (1975) Follicular plasminogen and plasminogen activator and the effect of plasmin on ovarian follicle wall. Cell 6, 379-386.

Espey, L.L. (1967a) Ultrastructure of the apex of the rabbit Graafian follicle during the ovulatory process. Endocrinology 81, 267-276.

Espey, L.L. (1967b) Tenacity of porcine Graafian follicle as it approaches ovulation. Am. J. Physiol. 212, 13971401.

Espey, L.L. (1970) Effects of various substances on tensile strength of sow ovarian follicles. Am. J. Physiol. 219, 230-233.

Espey, L.L. (1974) Ovarian proteolytic enzymes and ovulation. Biol. Reprod. 10, 216-235.

Espey, L.L. (1980) Ovulation as an inflammatory reaction-A hypothesis. Biol. Reprod. 22, 73-106.

Espey, L.L. \& Lipner, H. (1965) Enzyme-induced rupture of rabbit Graafian follicle. Am. J. Physiol. 208, 208213.

Fukuhara, K., Murao, S., Nozawa, T. \& Hatano, M. (1982) Structural elucidation of talopeptin (MK-I), a novel metallo proteinase inhibitor produced by Streptomyces mozunensis MK-23. Tetrahedron Lett. 23, 2319-2322.

Fukumoto, M., Yajima, Y., Okamura, H. \& Midorikawa, O. (1981) Collagenolytic enzyme activity in human ovary: An ovulatory enzyme system. Fert. Steril. 36, 746-750.

Hanada, $\overline{\mathbf{K}}$., Tamai, M., Yamagishi, M., Ohmura, S., Sawada, J. \& Tanaka, I. (1978) Isolation and characterization of E-64, a new thiol protease inhibitor. Agric. \& biol. Chem. 42, 523-528.

Ichikawa, S., Ohta, M., Morioka, H. \& Murao, S. (1983) Blockage of ovulation in the explanted hamster ovary by a collagenase inhibitor. $J$. Reprod. Fert. 68, 1719.

Kakinuma, A., Sugino, H., Moriya, N. \& Isono, M. (1978) Plasminostreptin, a protein proteinase inhibitor produced by Streptomyces antifibrinolyticus. J. biol. Chem. 253, 1529-1537.

Morales, T.I., Woessner, J.F., Howell, D.S., Marsh, J.M. \& LeMaire, W.J. (1978) A microassay for the direct demonstration of collagenolytic activity in Graafian follicles of the rat. Biochim. Biophys. Acta 524, 428434.

Morioka, H. \& Ichikawa, S. (1982) Ovulation in explanted hamster ovary. Japan. J. Anim. Reprod. 28, 201-205.
Murao, S. \& Sato, S. (1972) S-SI, a new alkaline protease inhibitor from Streptomyces albogriseolus S-3253. Agric. \& biol. Chem. 36, 160-163.

Murao, S. \& Satoi, S. (1971) New pepsin inhibitor (S-PI) from Streptomyces EF-44-201. Agric. \& biol. Chem. 34, 1265-1267.

Murao, S. \& Watanabe, T. (1977) Novel microbial alkaline protease inhibitor MAPI, produced by Streptomyces sp. No. WT-27. Agric. \& biol. Chem. 41, 1313-1314.

Murao, S., Katsura, M., Fukuhara, K. \& Oda, K. (1980) New metallo proteinase inhibitor (MK-I) produced by Streptomyces mozunensis MK-23. Agric. \& biol. Chem. 44, 701-703.

Rondell, P. (1970) Follicular processes in ovulation. Fedn Proc. Fedn Am. Socs. exp. Biol. 29, 1875-1879.

Sato, S. \& Murao, S. (1974) Complex formation of microbial alkaline protease inhibitor (S-SI) with subtilisin BPN $^{\prime}$ and its properties. Agric. \& biol. Chem. 38, 2227-2233.

Satoi, S. \& Murao, S. (1973) Inhibition of acid protease by a pepsin inhibitor (S-PI). Agric. \& biol. Chem. 37, 2579-2587.

Schochet, S.S. (1916) A suggestion as to the process of ovulation and ovarian cyst formation. Anat. Rec. 10, 447-457.

Suda, H., Aoyagi, T., Hamada, M., Takeuchi, T. \& Umezawa, H. (1982) Antipain, a new protease inhibitor isolated from Actinomycetes. J. Antibiot., Tokyo, Ser. $A$ 25, 263-266.

Umezawa, H., Aoyagi, T., Morishima, H., Kunimoto, S., Matsuzaki, M., Hamada, M. \& Takeuchi, T. (1970) Chymostatin, a new chymotrypsin inhibitor produced by Actinomycetes. J. Antibiot., Tokyo, Ser. A. 23, 425-427.

Umezawa, H., Aoyagi, T., Okura, A., Morishima, H., Takeuchi, T. \& Okami, Y. (1973) Elastatinal, a new elastase inhibitor produced by Actinomycetes. $J$. Antibiot., Tokyo, Ser. A 26, 787-789.

Watanabe, T. \& Murao, S. (1979) Purification and characterization of crystalline microbial alkaline proteinase inhibitors (MAPI), produced by Streptomyces nigrescens WT-27. Agric. \& biol. Chem. 43, 243250 .

Werb, Z. \& Aggeler, J. (1978) Proteases induce secretion of collagenase and plasminogen activator by fibroblasts. Proc. natn. Acad. Sci. U.S.A. 75, 1839-1843.

Yamada, K.M. \& Olden, K. (1978) Fibronectinsadhesive glycoproteins of cell surface and blood. Nature, Lond. 275, 179-184.

Received 24 November 1982 